\title{
The Role of Costimulatory Molecules in Allergic Disease and Asthma
}

\author{
Vincent Lombardi Abinav K. Singh Omid Akbari \\ Department of Molecular Microbiology and Immunology, Keck School of Medicine, University of Southern \\ California, Los Angeles, Calif., USA
}

Key Words

Costimulatory molecules $\cdot$ Allergy $\cdot$ Asthma

\begin{abstract}
The prevalence of allergic diseases has increased rapidly in recent years. It is well established that the deleterious allergic response is initiated by T-cell recognition of major histocompatibility class II-peptide complexes at the surface of antigen-presenting cells. While this first signal gives antigen specificity to the adaptive immune response, a second nonspecific costimulatory signal is required by $T$ cells to become fully activated. This signal is provided by interactions between antigen-presenting cells and $T$ cells through molecules borne at the surfaces of the two cell types. Depending on the type of molecules involved, this secondary signal can promote the development of an inflammatory allergic reaction or may favor immune regulation. Several molecules of the B7 family (CD80, CD86, PD-1, ICOS, CTLA-4) and tumor necrosis factor receptor family (OX40, CD30, 4-1BB, Fas, CD27, CD40) play an important role in delivering costimulatory signals in early and late phases of allergic response. Therefore, costimulatory molecules involved in promotion or prevention of allergic immune responses are potential targets for the development of novel therapeutic approaches. This review aims to recapitulate our current understanding of the relationship between allergic diseases and costimulatory molecules.

Copyright $\odot 2009$ S. Karger AG, Basel
\end{abstract}

\section{Introduction}

The prevalence of allergy is increasing worldwide, especially in Western countries $[1,2]$. This trend may be due to increased hygiene which prevents early exposure to microorganisms in infancy and increases the risk of developing an allergic disease in the future [3]. Air pollution may also favor the development of allergies [4]. Among allergic diseases, asthma is of particular concern as it can evolve into a life-threatening chronic pulmonary disease. It is now recognized that inhalation of aeroallergens by sensitized patients initiates a massive T helper 2 (TH2) cell response resulting in the production of interleukin-4 (IL-4), IL- 5 and IL-13 by CD4+ T cells [5]. This triggers the development of typical signs of bronchial asthma including airway hyperresponsiveness, bronchoconstriction, mucus secretion and airway remodeling. The recruitment, differentiation and activation of $\mathrm{TH} 2$ cells play a cardinal role in the development of allergic disease. This TH2 polarization is mainly controlled by antigenpresenting cells (APCs) that provide signals capable of supporting the differentiation of naïve T cells into TH2 cells.

Initially, Lafferty et al. [6] suggested that $\mathrm{T}$ lymphocytes require two coordinate signals to be fully activated. The first signal confers specificity to the immune response and plays an important role in the recognition of the major histocompatibility class-peptide complex at the

\section{KARGER}

두 2009 S. Karger AG, Basel

Fax +41613061234

E-Mail karger@karger.ch

www.karger.com
Accessible online at:

www.karger.com/iaa
Correspondence to: Dr. Omid Akbari

Department of Molecular Microbiology and Immunology, NRT 5505

Keck School of Medicine, University of Southern California

1450 Biggy St, Los Angeles, CA 90033-9605 (USA)

Tel. +1 323442 7930, Fax +1 323442 1721, E-Mail akbari@usc.edu 
surface of APCs by T lymphocytes. However, this primary signal is not sufficient to completely activate these $\mathrm{T}$ cells. To become fully effective, a second, nonspecific costimulatory signal is often required by $\mathrm{T}$ cells. These signals are provided by interactions between APCs and T cells through surface molecules expressed on T lymphocytes. APCs express costimulatory molecules such as CD80 (B7-1) and CD86 (B7-2) which belong to the B7 family. They provide modulation of T-cell function by ligation to their receptors, CD28 or cytotoxic T lymphocyte-associated antigen 4 (CTLA-4). Engagement of CD28 or CTLA- 4 has been observed to have opposite effects. CD28 promotes T-cell activation and survival while CTLA-4 inhibits T-cell responses and regulates peripheral T-cell tolerance [7]. This demonstration provides clear evidence that costimulatory molecules are involved in the fine tuning of the T-cell response by mediating both stimulatory as well as inhibitory signals. In many recent studies, numerous new costimulatory molecules have been described leading to the recognition that costimulation pathways are more complex than the classical two-signal model. In general, costimulatory molecules are divided into 2 main families: molecules from the $\mathrm{B} 7: \mathrm{CD} 28$ family, such as CTLA-4 or programmed death (PD)-L1, and from the tumor necrosis factor receptor (TNFR) superfamily such as OX40 or CD27 [8]. All these costimulatory molecules have particular effects on T-cell activation, function and survival (table 1) and are implicated in nearly all inflammatory diseases. Studies to better characterize the specific role of these molecules in allergy and asthma are still ongoing. In this review, we summarize current knowledge concerning the role of costimulatory molecules in allergy and analyze the potential functions of the emerging new subsets of costimulatory molecules recently described.

\section{Involvement of the B7:CD28 Family Molecules in the Regulation of Allergic Diseases}

The first costimulatory molecules described were the ligands of CD28: CD80 (B7-1) and CD86 (B7-2). The CD28 costimulation pathway is an important factor for the promotion of an effective antigen-specific immune response. However, CD28-deficient mice are still able to develop allergic airway inflammation showing that CD28 cannot be solely responsible for the development of an allergic response [9]. The expression of CD28 ligands (CD80 and CD86) has been extensively studied in clinical samples from asthmatic patients. Hofer et al. [10] reported that B lymphocytes from asthmatic patients exposed to allergens express higher levels of surface CD86, but not CD80, compared with those from asthmatic patients not exposed to allergen or with those from healthy individuals (table 1). Another study demonstrated that CD80 and, to a lesser extent, CD86 were upregulated at the surface of alveolar macrophages from allergic patients compared with those from pulmonary sarcoidosis, extrinsic allergic alveolitis patients or from normal subjects [11]. In contrast, Burastero et al. [12] observed that in allergic individuals, CD80, but not CD86, is highly expressed by alveolar macrophages. CD86 can also be expressed in a soluble form, where the transmembrane domain is deleted. This form is mostly produced by circulating monocytes and, like membrane-bound CD86, cross-links CD28 or CTLA-4 and activates T lymphocytes [13]. In patients with acute asthma, the level of soluble CD86 has been shown to be increased relative to that in patients with stable asthma or in healthy individuals [14]. Monocytes from allergic patients produce more soluble CD86 compared with those of healthy individuals [14]. It was also observed that the level of soluble CD86 is correlated with the severity of the airway hyperreactivity (AHR). These results are consistent with studies which show that the concentrations of soluble CD80 and soluble CD86 are elevated in asthmatic patients. Interestingly, the administration of a glucocorticoid (e.g., prednisolone), used to reduce airway inflammation in allergic patients, reduces the level of circulating CD86 [15]. Recently, Ritprajak et al. [16] demonstrated that the topical administration of a silencer RNA specific to the CD86 gene reduced local inflammation in a mouse model of atopic dermatitis by decreasing the recruitment of dendritic cells (DCs) into the skin, production of antigen-specific IL-4 and induction of serum immunoglobulin E (IgE) and IgG1. It has also been reported that pulmonary tolerogenic DCs stimulated by allergen exposure express high levels of both CD80 and CD86 [17]. Taken together, these studies suggest that overexpression of CD80 and/or CD86 is correlated with the development of allergic disease and asthma.

Within the B7 family, CD28 and inducible costimulator (ICOS) are most homologous with respect to structure and function. Both are type I transmembrane receptors expressed as homodimers, with an extracellular (Ig)V-like domain, a hallmark of receptors of the B7-related family [18]. ICOS expression is induced in vitro within $24-48 \mathrm{~h}$ of activation on all T helper-primed cells $[18,19]$. ICOS has been shown to regulate the production of $\mathrm{TH} 2$ cytokines [20] and plays a critical role in lung mu- 
Table 1. Role of costimulatory molecules in allergic disease and asthma

\begin{tabular}{|c|c|c|c|}
\hline $\begin{array}{l}\text { Costimulatory } \\
\text { molecule family }\end{array}$ & APC & $\begin{array}{l}\text { Effector } \\
\text { cell }\end{array}$ & Functions and characteristics \\
\hline \multirow[t]{6}{*}{ B7 } & \multirow[t]{2}{*}{$\begin{array}{l}\text { CD80 } \\
\text { CD86 }\end{array}$} & CTLA-4 & $\begin{array}{l}\text { Contributes to the suppressive activity of allergen-specific regulatory cells during sensitization } \\
\text { Polymorphism in Ctla-4 promoter and gene favors allergic diseases }\end{array}$ \\
\hline & & CD28 & $\begin{array}{l}\text { CD80 and CD86 expression is upregulated on the surface of various cells of allergic patients } \\
\text { Soluble CD86 is increased in the sera of allergic patients }\end{array}$ \\
\hline & ICOS-L & ICOS & $\begin{array}{l}\text { Regulates TH2-effector cell function and their infiltration in the lungs, production of TH2 } \\
\text { cytokine } \\
\text { Promotes B-cell differentiation and IgE production } \\
\text { Expression on iNKT cells contributes to airway hyperreactivity } \\
\text { Contributes to the differentiation of regulatory cells in pulmonary lymph nodes }\end{array}$ \\
\hline & $\overline{\mathrm{PD}-\mathrm{L} 1}$ & PD-1 & $\begin{array}{l}\text { Drives the differentiation of Foxp } 3+\mathrm{CD} 4+\mathrm{T} \text { cells } \\
\text { Downregulates contact hypersensitivity reaction }\end{array}$ \\
\hline & PD-L2 & PD-1 & $\begin{array}{l}\text { Regulates asthma by an IFN- } \gamma \text {-dependent mechanism } \\
\text { Downregulates airway hyperreactivity, prevents eosinophil infiltration in the lungs and } \\
\text { prevents IgE production }\end{array}$ \\
\hline & $\overline{\mathrm{B} 7-\mathrm{H} 3}$ & $\begin{array}{l}\text { Receptor } \\
\text { unknown }\end{array}$ & $\begin{array}{l}\text { Promotes TH2 differentiation, eosinophil infiltration and development of airway } \\
\text { hyperreactivity } \\
\text { Decreases the severity of allergic conjunctivitis }\end{array}$ \\
\hline \multirow[t]{6}{*}{ TNFR } & OX40L & OX40 & $\begin{array}{l}\text { Promotes the development of } \mathrm{TH} 2 \text { cells } \\
\text { Prevents differentiation of } \mathrm{T}_{\text {reg }} \text { cells } \\
\text { Abrogates mast cell degranulation }\end{array}$ \\
\hline & CD30-L & CD30 & $\begin{array}{l}\text { CD30 is expressed by Langerhans cells, CD } 4+\text { and CD } 8+\mathrm{T} \text { cells of atopic patients } \\
\text { Soluble CD30 is increased in the sera of allergic patients }\end{array}$ \\
\hline & 4-1BB-L & $4-1 B B$ & $\begin{array}{l}\text { Promotes airway hyperreactivity, eosinophil infiltration and IgE production } \\
\text { Upregulates TH2 cell proliferation and mast cell cytokine production }\end{array}$ \\
\hline & Fas & FasL & $\begin{array}{l}\text { Delays resolution of airway hyperresponsiveness } \\
\text { Promotes eosinophil apoptosis in the lungs }\end{array}$ \\
\hline & $\mathrm{CD} 27$ & CD70 & Increases production of IgE by B cells \\
\hline & $\overline{\mathrm{CD} 40}$ & CD40L & $\begin{array}{l}\text { Contributes to isotype class switching towards IgE } \\
\text { Enhances development of airway inflammation } \\
\text { Increases production of } \mathrm{TH} 2 \text { cytokine and decreases number of } \mathrm{T}_{\text {reg }} \text { cells }\end{array}$ \\
\hline $\begin{array}{l}\text { Other } \\
\text { costimulatory } \\
\text { molecules }\end{array}$ & $\mathrm{CD} 2$ & CD58 & $\begin{array}{l}\text { Promotes differentiation of TH2 cells and the production of IgE } \\
\text { Expressed on monocytes of allergic patients }\end{array}$ \\
\hline
\end{tabular}

cosal inflammatory responses [21]. Furthermore, this costimulatory molecule has been suggested not only to intensify some of the functions of CD28 during an already established immune response but also to induce additional T-effector cell functions [22]. Recent studies suggest that ICOS-mediated costimulation may regulate TH2-effector cell function without affecting TH2 differentiation [23]. Another study showed that transfer of ICOS-enriched $\mathrm{T}$ cells followed by allergen airway challenge induced infiltration of recipient $\mathrm{T}$ and $\mathrm{B}$ cells as well as local production of allergen-specific IgE by intrapulmonary plasma cells [24]. In contrast, transfer of the
ICOS-depleted T-cell fraction resulted in the recruitment of significantly lower numbers of B cells with no local IgE production. These data indicate that expression of ICOS defines a subset of $\mathrm{T}$ effector cells that are required for $\mathrm{B}$ cell infiltration and local IgE production in lung tissue. According to Tesciuba et al. [23], ICOS stimulation increases the migration of lymphocytes into draining lymph nodes by augmenting the expression of attractant chemokines CCL21 and CXCL13. In other reports, the increased production of IL-5, which is a main factor for the differentiation, maturation and recruitment of eosinophils, is attributed to ICOS+ cells [24]. ICOS+ T cells 
also promote the differentiation of B cells and IgE-producing plasma cells through the enhanced production of IL-4 and IL-10 [25]. ICOS-deficient mice are unable to induce high IgE responses demonstrating their role in the induction of IgE production [26]. Some studies also suggest that intermediate ICOS expression is associated with high production of $\mathrm{TH} 2$ cytokines, whereas high levels of ICOS predominantly translate into high IL-10 production [27]. Surprisingly, ICOS/ICOS-L interaction not only promotes the development of TH2-driven inflammation but also mediates mucosal tolerance, as studies have indicated that pulmonary DCs in the bronchial lymph nodes of mice exposed to respiratory allergen induced the costimulation of regulatory $\mathrm{T}$ cells $\left(\mathrm{T}_{\text {reg }}\right.$ cells) via the ICOS/ICOS-L pathway [28]. These $\mathrm{T}_{\text {reg }}$ cells produce IL10 , show inhibitory activity and, when adoptively transferred into sensitized mice, have the ability to inhibit the development of AHR. These reports suggest that both the development and inhibitory function of $\mathrm{T}_{\text {reg }}$ cells are depending upon the presence of IL-10 and ICOS/ICOS-L interaction. Studies in ICOS-deficient patients supported the findings in mice by demonstrating that CD4+ T cells in those patients cannot be skewed towards suppressive or anergic phenotype [29]. Interestingly, Taylor et al. [30] demonstrated that IL-10 suppresses CD28 and ICOS-mediated T-cell costimulation by a mechanism dependent on Src homology 2 domain-containing protein tyrosine phosphatase 1 (SHP-1). Specifically, IL-10 ligation to its receptor triggers Tyk 2 activation followed by SHP-1 phosphorylation. This active form of SHP-1 dephosphorylates the costimulatory molecules CD28 and ICOS. Thus, signal transduction downstream of engagement of either molecule is abolished and T-cell activation through these costimulatory molecules is impaired. Beside IL-10, ICOS is involved in expression and differentiation of IL-17-producing helper T cells [31]. A recent study by Bauquet et al. [31] suggests that there are significantly lower levels of IL17 from T cells in ICOS-deficient mice. The authors suggest that engagement of ICOS induces the expression of c-Maf, which regulates IL-21 production and controls the expansion of TH17 cells. Beyond the role of ICOS on T cells, two recent studies have demonstrated the importance of ICOS in iNKT cell function in the development of AHR and in the homeostasis and survival of CD4+ iNKT cells. ICOS expression is upregulated on iNKT cells upon $\alpha$-galactosylceramide stimulation. Moreover, blockade of the ICOS pathway using a specific antibody or gene knock-out strategy abrogates cy totoxicity and cytokine production triggered by $\alpha$-galactosylceramide treatment [32]. The number of CD4+ iNKT cells were greatly reduced in the periphery but not in the thymus of both ICOS-/- and ICOS-L-/- mice compared with wildtype mice, indicating that ICOS/ICOS-L interactions are critical in homeostatic survival of CD4 iNKT cells [19]. In contrast, the number of iNKT cells and the level of ICOS expression in CD28-/- mice is comparable with that in wild-type mice, suggesting that signaling via ICOS but not via $\mathrm{CD} 28$ plays a unique role in regulation of CD4 iNKT cell homeostatic survival. Thus, the iNKT cells expressing ICOS contribute significantly to the development of AHR.

CTLA- 4 has been described to be an important regulator of T-cell activation. CTLA-4 is constitutively and exclusively expressed by $\mathrm{T}$ lymphocytes in both mice and humans [7]. CTLA-4 expression confers to T-lymphocyte regulatory functions [33]. Indeed, the contribution of CTLA- 4 in the regulation of the immune system is demonstrated by the development of multiple organ autoimmune pathologies and lymphoproliferative disease in CTLA-4-deficient mice [34, 35]. Blockade of CTLA-4 activity abolishes the suppressive function of CD4+ CD25+ T cells [33]. In a mouse model of inflammatory bowel disease, the effect of transfer of a population of CD4+ $\mathrm{CD} 45 \mathrm{RB}^{\text {low }} \mathrm{T}_{\text {reg }}$ cells in decreasing intestinal inflammation is abrogated by the coadministration of a blocking anti-CTLA-4 antibody (table 1) [36]. These studies suggest that the engagement of CTLA- 4 at the surface of $\mathrm{T}_{\text {reg }}$ cells by its ligands CD80 or CD86 contributes to the regulation of suppressive functions of $\mathrm{T}_{\text {reg }}$ cells. Polymorphism in CTLA-4 gene is also considered a risk factor for allergy and asthma. Howard et al. [37] characterized four single nucleotide polymorphisms which were related to allergic and asthma phenotypes. They demonstrated that these specific polymorphisms alone or in combinations are correlated with an elevated IgE titer or bronchial hyperresponsiveness in patients with asthma. Interestingly, in the same study, no correlation between allergic phenotype and single nucleotide polymorphisms for CD28 was observed. In a similar report, Lee et al. [38] studied the impact of two polymorphisms in the CTLA-4 promoter $(-318 \mathrm{C} / \mathrm{T})$ and gene $(+49 \mathrm{C} / \mathrm{G})$ [39]. They demonstrated that a polymorphism at the level of the promoter was correlated to asthma severity while the $+49 \mathrm{C} / \mathrm{G}$ polymorphism is associated with airway hyperresponsiveness. These findings confirm that CTLA-4 is indeed involved in the course of allergic diseases. Furthermore, CTLA-4 is often considered as a marker of $\mathrm{T}_{\text {reg }}$ cells. In that regard, Meiler et al. [40] demonstrated that, in response to multiple bee stings, beekeepers develop a protective immune response by the development of antigen-specific type 1 
regulatory $\mathrm{T}$ cells. The authors observed that in peripheral blood mononuclear cells isolated from beekeepers, the suppressive activity of antigen-specific IL-10-secreting cells is blocked by an anti-CTLA- 4 and an anti-PD-1 antibody. The authors confirmed the role of CTLA- 4 in the suppressive activity of $\mathrm{T}_{\text {reg }}$ cells in humans and suggest that the engagement of CTLA- 4 on $\mathrm{T}_{\text {reg }}$ cells leads to reduced T-cell-receptor-derived signaling which is required for the induction of the suppressive activity [40]. Similarly, analysis of Bet v 1-specific CD4+ T cells from healthy individuals at the single-cell level using major histocompatibility class II peptide tetramer revealed that a fraction of these cells expressed CTLA-4 and Foxp3, suggesting that they represent a population of $\mathrm{T}_{\text {reg }}$ cells [41]. Interestingly, CTLA-4 seems to play a more important role in the sensitization phase than in established allergy. In a model of mice sensitized with grass pollen, the administration of a blocking anti-CTLA-4 or a blocking anti-CD154 (anti-CD40L) antibody during the sensitization phase prevents the production of allergen-specific antibody. In contrast, in sensitized mice, anti-CTLA- 4 or anti-CD154 antibodies failed to decrease the level of allergen-specific IgE [42].

The PD-1 receptor and its ligands $\mathrm{PD}-\mathrm{L} 1 \mathrm{(B7- \textrm {H } 1 )}$ and PD-L2 (B7-DC) belong to the B7:CD28 family of receptors. The PD-1 receptor was initially discovered in T cells undergoing cell death [43]. The inhibitory signal provided by engagement of PD-1 was demonstrated by the development of autoimmune diseases in PD-1-deficient mice [44]. Several groups have subsequently reported that engagement of PD-1 by PD-L1 or PD-L2 results in inhibition of proliferation and polarized or altered cytokine production [45-47]. Studies are just beginning to elucidate PD-L1 and PD-L2 function in allergy and asthma. In a mouse model of asthma, Matsumoto et al. [48, 49] demonstrated that PD-L2 is highly expressed on pulmonary DCs and macrophages of sensitized mice. Moreover, administration of blocking antibody against PD-L2, but not PD-1 or PD-L1, during challenge enhances the airway hyperresponsiveness and production of $\mathrm{TH} 2$ cytokines (table 1) [49]. This effect is mediated by interferon (IFN)- $\gamma$, given that no improvement is observed in IFN$\gamma$-deficient mice following treatment with anti-PD-L2 [48]. In addition, administration of the sHIgM12 antibody (an antibody inducing reverse signaling through PD-L2) in a mouse model of allergic asthma blocks the development of AHR [50]. An additional study demonstrates that administration of PD-L2-Fc in a mouse model of allergic asthma resulted in elevated levels of serum IgE and increased eosinophilic and lymphocytic infiltra- tion into the bronchoalveolar lavage fluid [51]. These studies emphasize the pivotal role of PD-L2 in the development of allergic asthma. In addition, in a model of experimental allergic conjunctivitis, treatment with antiPD-L2 blocking antibody during the effector phase enhanced infiltration of eosinophils into the conjunctiva without change in the systemic response [52]. Finally, using PD-L2-deficient mice, it was reported that this molecule is dispensable for $\mathrm{TH} 2$ differentiation and required for the induction of mucosal tolerance [53]. Taken together, these reports strongly suggest that PD-L2 is involved in the downregulation of $\mathrm{TH} 2$-allergic immune response. In a mouse model of hapten-induced contact hypersensitivity, Kim et al. [54] demonstrated that blockade of PDL1 enhanced the activity of hapten-specific T cells and the administration of hapten-carrying PD-L1 on DC-induced tolerance in animals sensitized by hapten challenge. Similarly, Tsushima et al. [55] demonstrated that anti-PD-L1 blocking antibody, but not anti-PD-L2 blocking antibody, enhanced contact hypersensitivity reaction, possibly by increasing the proliferative response of $\mathrm{T}$ cells in response to hapten-pulsed APCs. This suggests a unique role of PD-L1 in the regulation of inflammatory responses (table 1). Piconi et al. [56] had reported earlier that during allergen-specific immunotherapy, the expression of $\mathrm{PD}-\mathrm{L} 1$ on both monocytes and $\mathrm{B}$ lymphocytes is increased relative to that in the untreated control group. The authors proposed that PD-L1 could be used as a marker to monitor the effect of allergen-specific immunotherapy and could also be targeted to enhance immunosuppression. A subset of PD-L1-positive tolerogenic Langerhans cells was described by Allam et al. [57] in the sublingual mucosa in humans. The authors observed that upon stimulation by a Toll-like receptor 4 (TLR4) ligand, these cells release a higher level of IL-10 compared with untreated control cells. These Langerhans cells have decreased capacity to stimulate $T$ cells and are able to support the differentiation of $\mathrm{T}_{\text {reg }}$ cells expressing Foxp3, producing IL-10 and transforming growth factor- $\beta$ [58]. These sublingual tolerogenic Langerhans cells stimulated via their TLR4 expressed higher levels of the coinhibitory molecules PD-L1 and B7-H3, while CD86 expression is lowered. Consequently, the expression of these molecules by APCs seems to be linked with tolerogenic properties. These studies represent a body of evidence which suggests that PD-L1 is involved in the maintenance of the peripheral tolerance and may contribute to the induction of allergy. Clearly, further work is required to understand the role of PD-1 and its ligands in allergic diseases and asthma. 
The precise role of the other ligands of the B7 family, such as B7-H3, is far less clear. The ligand of B7-H3 is still unknown but seems to be present at the surface of activated $\mathrm{T}$ cells [40]. A recent study proposed that $\mathrm{B} 7-\mathrm{H} 3$ supports the differentiation of $\mathrm{TH} 2$ cells during sensitization in animal models of asthma, as blocking B7-H3 with an antibody results in a decreased production of $\mathrm{TH} 2$ cytokines in draining lymph nodes, reduced infiltration of eosinophils in lungs and in reduced AHR [59]. In contrast, administration of blocking B7-H3 antibody during the sensitization phase increases the severity of allergic conjunctivitis in mice, possibly by inducing IL- 5 production in the spleen [60]. These studies indicate that $\mathrm{B} 7-\mathrm{H} 3$ is potentially involved in the regulation of allergic disease and asthma. However, many questions pertaining to B7-H3 will still need to be addressed in future mechanistic and prospective studies.

\section{The Role of TNFR Costimulatory Molecules in Allergy and Asthma}

Members of the TNFR superfamily can have distinctive cytoplasmic death domains which are involved in apoptotic signaling. Other members of the superfamily lack such a domain, with no apparent homology in the cytoplasmic tail. This latter group of receptors is involved in gene activation and antiapoptotic signaling. The role in allergy of TNFR family members such as OX-40, 4-1BB, CD30, Fas, CD27 and CD40 has been recently studied and reported by several investigators.

OX40 and its ligands play an important role in costimulation of allergen-specific lymphocytes. Activated CD4+ T cells express OX40, whereas OX40L is mainly expressed by APCs $[61,62]$. It was observed that ligation of OX40 increases IL-4 production by naïve cells and promotes their development into effector cells producing high levels of the TH2 cytokines IL-4, IL-5 and IL-13 [62]. OX40-OX40L interaction also plays an important role in deciding the fate of $\mathrm{CD} 4+\mathrm{T}$ cells during allergic inflammation. It was reported that OX40L expressed by thymic stromal lymphopoietin-activated DCs enables these APCs to trigger allergic inflammatory $\mathrm{TH} 2 \mathrm{re}$ sponses [63]. In a similar study, Ito et al. [63] showed that blocking of OX40-OX40L interaction inhibits the production of TNF- $\alpha$ and TH 2 cytokines and enhances the production of IL-10. In allergen-induced models of asthma, OX40- or OX40L-deficient mice exhibit markedly impaired reactivation of $\mathrm{TH} 2$ memory cells and $\mathrm{TH} 2 \mathrm{re}-$ sponses as well as diminished lung inflammation [64,
65]. OX40-deficient mice developed a weak TH2 response and airway inflammation after sensitization to ovalbumin indicating the cardinal role of this molecule in the initiation of allergic immune responses [66]. Additionally, Duan et al. [67] reported that intranasal exposure to lipopolysaccharide/endotoxin leads to the interaction between OX40 and OX40L, which, with other inflammatory effects of TLR4 signaling, alters the balance between Foxp3 $+\mathrm{T}_{\text {reg }}$ cells and effector T cells and influences the susceptibility to allergic inflammatory disease. Moreover, it was reported that OX40 inhibits the development of adaptive Foxp $3+\mathrm{T}_{\text {reg }}$ cells from naïve $\mathrm{CD} 4+$ T-cell populations in response to transforming growth factor- $\beta[68,69]$. These studies suggest that preventing OX40-OX40L interaction might be beneficial in improving the effectiveness of allergen immunotherapy as those interactions might induce mucosal tolerance through development of regulatory cells. Interestingly, OX40L can also be present at the surface of mast cells, which play a pivotal role in allergy. $\mathrm{T}_{\text {reg }}$ cells can abrogate mast cell degranulation following FceRI engagement by IgE, via OX40-OX40L interaction [70].

Similarly to ICOS, OX40-OX40L interaction can modulate the function of iNKT cells which also play an important role in allergic disease and asthma. A recent report suggests that iNKT cells interact with plasmacytoid DCs via OX40-OX40L interaction, downregulate the CD8+ immune response and prevent tissue damage [71], while iNKT stimulated with OX40L-expressing DCs produces more IFN- $\gamma$ and CD69 [72]. However, the phenotypical difference between OX40-deficient and OX40Ldeficient mice suggests that OX40 might have more than 1 ligand; thus, it is difficult to draw a definite conclusion regarding OX40L.

Several clinical studies have revealed a link between the upregulation of CD30 and allergic diseases and asthma. Initially, it was reported that the concentration of the soluble form of CD30 is higher in patients with asthma or atopic dermatitis than in healthy controls and correlates directly with the severity of the disease $[73,74]$. In atopic dermatitis patients, CD30 expression is increased at the surface of Langerhans cells, CD4+ and CD8+ T cells [74, 75]. Rojas-Ramos et al. [75] demonstrated that the level of CD30 expression at the surface of CD4+ T cells was correlated with the production of IL- 4 after restimulation of $\mathrm{CD} 4+\mathrm{T}$ cells isolated from allergic patients. These data suggest that the expression of CD30 at the surface of different immune cells or in a soluble form in the serum could be linked to a $\mathrm{TH} 2$ polarization. A recent study demonstrating a reduction of the level of soluble CD30 in 
venom-specific immunotherapy also suggests a relationship between TH2 activity and CD30 expression [76].

Another member of the TNFR superfamily is $4-1 \mathrm{BB}$ (CD137), which has been suggested to suppress antigenspecific helper $\mathrm{T}$ cells and $\mathrm{B}$ cell-dependent humoral immune response [77]. Additionally, $4-1 \mathrm{BB}$ is specifically expressed by eosinophils from atopic patients with IgEmediated dermatitis or asthma [78]. In a mouse model of allergic asthma, 4-1BB blocking antibody decreased airway hyperresponsiveness and reduced the level of allergen-specific IgE in sera of sensitized mice [79]. Also, pulmonary $\mathrm{T}$ lymphocytes of anti-4-1BB-treated mice showed a decreased proliferation and produced less IL-5 in response to ovalbumin. However, IL-4 and IL-5 levels in BAL fluid were only marginally reduced. $4-1 \mathrm{BB}$ is also expressed by mast cells and acts as a costimulatory molecule when mast cells are stimulated through their FceRI. Agonistic anti-4-1BB antibody enhances mast cell cytokine production after engagement of FceRI [80]. Polte et al. [81] demonstrated that in a mouse model of asthma, prophylactic administration of a blocking anti-4-1BB is capable of preventing the establishment of airway hyperresponsiveness, eosinophil infiltration and production of allergen-specific IgE and reduces the production of TH2 cytokines while enhancing secretion of TH1 cytokines. Depletion of CD8 + cells or blockade of IFN- $\gamma$ abolished the protective effect of 4-1BB blocking antibody, which suggests that the effect of 4-1BB is dependent on IFN- $\gamma$ producing $\mathrm{CD} 8+\mathrm{T}$ cells [82]. Interestingly, after sensitization, injection of anti-4-1BB blocking antibody totally reverses the allergic phenotype in mice, which suggests that intervention within the 4-1BB pathway might offer a novel therapeutic approach in patients with asthma. Finally, in a similar approach using a model of atopic conjunctivitis, treatment with an agonistic anti-4-1BB before or after sensitization abolished the development of allergic conjunctivitis [83].

The CD95 (Fas or APO-1) antigen is a $40-$ to $50-\mathrm{kDa}$ transmembrane glycoprotein that also belongs to the TNF superfamily. This cell surface molecule mediates apoptosis (programmed cell death) and is strongly upregulated on activated $\mathrm{T}$ cells, $\mathrm{B}$ cells, natural killer cells and thymocytes. In the field of allergy, it is important to note that Fas is also expressed by eosinophils in sensitized mice [84], and stimulation of this receptor with an antiFas antibody triggers apoptosis of eosinophils. In vivo studies have also shown that lung eosinophilia is reduced by administration of anti-Fas antibody. Moreover, failure of induction of eosinophil apoptosis by Fas/FasL interaction could explain the chronic eosinophilic airway in- flammation found in patients with asthma. Fas-deficient mice sensitized to ovalbumin show a delayed AHR resolution compared with wild-type mice [85], an observation that could be explained by a decreased apoptosis of eosinophils and effector $\mathrm{T}$ cells. In this regard, a study by Tong et al. [86] proposed that this delayed resolution of eosinophilia in Fas-deficient mice is due to the absence of Fas on $\mathrm{T}$ cells but not on eosinophils. Consistent with those studies is the observation that transfer of DCs genetically engineered to express FasL significantly reduces induction of AHR in sensitized recipients [87]. On the other hand, Uller et al. [88] showed that anti-Fas antibody exacerbates established airway inflammation since stimulation of Fas receptor by eosinophils triggers cytolysis and causes secondary necrosis of apoptotic eosinophils. Therefore, time kinetics and location of Fas/FasL expression play a major role in the regulation of immune responses in allergy and asthma.

CD27 is a type I glycoprotein expressed on T and B cells and also belongs to the TNFR family. The ligand for CD27 is CD70, another member of the TNF family [89], which is expressed not only on activated B cells but also on $\mathrm{T}$ cells, particularly on activated CD4+ CD45RO+ T cells [90]. It has been demonstrated that the CD27/CD70 interaction is involved in the differentiation of $\mathrm{B}$ cells into plasma cells $[17,18]$. The roles of CD27 and CD70 as costimulatory molecules in allergic diseases are less clear. One report suggests that B cells transfected with a plasmid expressing CD70 significantly augments IgE production by enhancing B-cell proliferation and differentiation into plasma cells. However, another recent report shows that CD27 and CD70 do not play a role in the development of experimental allergic conjunctivitis in mice [91]. Although it seems that the effects of CD27/CD70 interaction on B-cell and Ig synthesis in the murine and human systems are somewhat different, more experiments in both animal models and humans need to be done to further clarify their role in allergy and asthma.

Another member of the TNFR superfamily, CD40, is a costimulatory protein found on APCs and is required for their activation. This receptor has been found to be essential in mediating a broad variety of immune and inflammatory responses including $\mathrm{T}$ cell-dependent immunoglobulin class switching, memory B-cell development, germinal center formation, B- and T-lymphocyte activation and regulation [92]. During allergen sensitization, cooperation between $\mathrm{T}$ and $\mathrm{B}$ lymphocytes through CD40-CD40L interaction is a fundamental signal to trigger isotype class switching towards IgE [93]. CD40 is also expressed at the surface of airway epithelial cells. Its en- 
gagement increases the production of inflammatory mediators suggesting that CD40 ligation favors airway inflammation [94, 95]. Recently, Suzuki et al. [96] showed that the inhibition of CD40 expression using small interfering RNA in ovalbumin-sensitized mice results in a decreased production of $\mathrm{TH} 2$ cytokines and increases the number of $\mathrm{T}_{\text {reg }}$ cells.

\section{Other Costimulatory Molecules Involved in the Regulation of Allergy and Asthma}

CD2 is a member of the immunoglobulin superfamily and is expressed on all peripheral blood T cells. It is one of the earliest T-cell markers, being present on more than $95 \%$ of thymocytes, and is also found on some natural killer cells but not on B lymphocytes. CD2 interacts with lymphocyte function-associated antigen-3 to mediate adhesion between $\mathrm{T}$ cells and other cell types [97]. CD2 is also considered as a costimulatory molecule on $\mathrm{T}$ and natural killer cells. Engagement of this receptor by its ligand lymphocyte function-associated antigen-3 induces T-cell proliferation and cytokine production [98]. CD2 engagement seems to inhibit TH1 activity while favoring TH2 development [99]. In a model of mercury chlorideinduced autoimmune disease in mice, administration of a specific $\mathrm{CD} 2$ antibody increased the production of $\mathrm{TH} 2$ cytokines such as IL- 4 and increased the serum level of IgE and IgG1 autoantibodies. Interestingly, the CD2 costimulation signal can be counteracted by regulatory cytokines such as IL-10 [100]. Since CD2 is also expressed by monocytes, the high CD2 expression on monocytes defines a population with elevated FceRI expression [101]. In asthmatic patients, CD2 expression at the surface of these monocytes is correlated with the level of plasma IgE. In addition, administration of an anti-IgE (omaliz- umab) decreases the expression of FceRI at the surface of $\mathrm{CD} 2^{\text {high }}$ monocytes. Therefore, it has been proposed that monocytes expressing a high level of CD2 represent an attractive target for the treatment of allergic disease and asthma.

\section{Conclusion}

Families of costimulatory molecules are involved in the regulation of most inflammatory diseases by finely controlling the intensity of the immune response. Costimulatory molecules are implicated in the development and control of allergic inflammation characterized by the establishment of an acute TH2 polarization. Elucidation of the role of costimulation pathways in the development of new subsets of T helper cells has just begun, and most of the mechanisms underlying the regulation of atopic diseases by costimulatory molecules are unknown and require further investigation. With an increased understanding of these immunological mechanisms, new therapeutic strategies in the treatment of allergic airway diseases can be created by analyzing the role of costimulatory molecules which are critically involved in the induction and maintenance of allergen-induced airway diseases. Taken together, recent studies have begun to provide insight into the role of costimulatory molecules and give us new clues to design more efficient therapies to fight the increasing public health problem that allergies represent.

\section{Acknowledgment}

O.A. was supported by grant NIH R01 AI066020.

\section{References}

1 Masoli M, Fabian D, Holt S, Beasley R: The global burden of asthma: executive summary of the GINA dissemination committee report. Allergy 2004;59:469-478.

2 Bousquet J, Khaltaev N: Global Surveillance, Prevention and Control of Chronic Respiratory Diseases. Geneva, World Health Organization, 2007, pp 15-20.

3 Tse K, Horner AA: Allergen tolerance versus the allergic march: the hygiene hypothesis revisited. Curr Allergy Asthma Rep 2008;8: 475-483.
4 Kim H, Bernstein JA: Air pollution and allergic disease. Curr Allergy Asthma Rep 2009;9:128-133.

$\checkmark 5$ Meiler F, Zimmermann M, Blaser K, Akdis CA, Akdis M: T cell subsets in the pathogenesis of human asthma. Curr Allergy Asthma Rep 2006;6:91-96.

-6 Lafferty KJ, Cooley MA, Woolnough J, Walker KZ: Thyroid allograft immunogenicity is reduced after a period in organ culture. Science 1975;188:259-261.
7 Greenwald RJ, Freeman GJ, Sharpe AH: The B7 family revisited. Annu Rev Immunol 2005:23:515-548.

8 Croft M: Co-stimulatory members of the TNFR family: keys to effective T cell immunity? Nat Rev Immunol 2003;3:609-620.

-9 Burr JS, Kimzey SL, Randolph DR, Green JM: CD28 and CTLA4 coordinately regulate airway inflammatory cell recruitment and $\mathrm{T}$ helper cell differentiation after inhaled allergen. Am J Respir Cell Mol Biol 2001;24:563568 
10 Hofer MF, Jirapongsananuruk O, Trumble AE, Leung DY: Upregulation of B7.2, but not B7.1, on B cells from patients with allergic asthma. J Allergy Clin Immunol 1998;101: 96-102.

-11 Agea E, Forenza N, Piattoni S, Russano A, Monaco A, Flenghi L, Bistoni O, Gillies DA, Azuma M, Bertotto A, Spinozzi F: Expression of B7 co-stimulatory molecules and CD1a antigen by alveolar macrophages in allergic bronchial asthma. Clin Exp Allergy 1998;28:1359-1367.

-12 Burastero SE, Magnani Z, Confetti C, Abbruzzese L, Oddera S, Balbo P, Rossi GA, Crimi E: Increased expression of the CD80 accessory molecule by alveolar macrophages in asthmatic subjects and its functional involvement in allergen presentation to autologous Th2 lymphocytes. J Allergy Clin Immunol 1999;103:1136-1142.

13 Jeannin P, Magistrelli G, Aubry JP, Caron G, Gauchat JF, Renno T, Herbault N, Goetsch L, Blaecke A, Dietrich PY, Bonnefoy JY, Delneste Y: Soluble CD86 is a costimulatory molecule for human T lymphocytes. Immunity 2000;13:303-312.

14 Shi HZ, Xie ZF, Deng JM, Chen YQ, Xiao CQ: Soluble CD86 protein in serum samples of patients with asthma. Thorax 2004;59: 870-875.

15 Deng JM, Shi HZ, Qin XJ, Xie ZF, Huang CP, Zhong XN: Effects of allergen inhalation and oral glucocorticoid on concentrations of serum-soluble CD86 in allergic asthmatics. Clin Immunol 2005;115:178-183.

-16 Ritprajak P, Hashiguchi M, Azuma M: Topical application of cream-emulsified CD86 siRNA ameliorates allergic skin disease by targeting cutaneous dendritic cells. Mol Ther 2008;16:1323-1330.

17 Akbari O, DeKruyff RH, Umetsu DT: Pulmonary dendritic cells producing IL-10 mediate tolerance induced by respiratory exposure to antigen. Nat Immunol 2001;2: 725-731.

18 Hutloff A, Dittrich AM, Beier KC, Eljaschewitsch B, Kraft R, Anagnostopoulos I, Kroczek RA: ICOS is an inducible T cell costimulator structurally and functionally related to CD28. Nature 1999;397:263-266.

-19 Akbari O, Stock P, Meyer EH, Freeman GJ, Sharpe AH, Umetsu DT, DeKruyff RH: ICOS/ICOSL interaction is required for CD4+ invariant NKT cell function and homeostatic survival. J Immunol 2008; 180: 5448-5456.

-20 McAdam AJ, Chang TT, Lumelsky AE, Greenfield EA, Boussiotis VA, Duke-Cohan JS, Chernova T, Malenkovich N, Jabs C, Kuchroo VK, Ling V, Collins M, Sharpe AH, Freeman GJ: Mouse inducible costimulatory molecule (ICOS) expression is enhanced by CD28 costimulation and regulates differentiation of CD4+ T cells. J Immunol 2000;165: 5035-5040.
21 Gonzalo JA, Tian J, Delaney T, Corcoran J, Rottman JB, Lora J, Al-garawi A, Kroczek R, Gutierrez-Ramos JC, Coyle AJ: ICOS is critical for T helper cell-mediated lung mucosal inflammatory responses. Nat Immunol 2001;2:597-604.

22 Tesciuba AG, Subudhi S, Rother RP, Faas SJ, Frantz AM, Elliot D, Weinstock J, Matis LA, Bluestone JA, Sperling AI: Inducible costimulator regulates Th2-mediated inflammation, but not Th2 differentiation, in a model of allergic airway disease. J Immunol 2001; 167:1996-2003.

23 Tesciuba AG, Shilling RA, Agarwal MD, Bandukwala HS, Clay BS, Moore TV, Weinstock JV, Welcher AA, Sperling AI: ICOS costimulation expands Th2 immunity by augmenting migration of lymphocytes to draining lymph nodes. J Immunol 2008; 181: 1019-1024.

24 Beier KC, Hutloff A, Lohning M, Kallinich T, Kroczek RA, Hamelmann E: Inducible costimulator-positive $\mathrm{T}$ cells are required for allergen-induced local B-cell infiltration and antigen-specific IgE production in lung tissue. J Allergy Clin Immunol 2004;114: 775-782.

25 Kobayashi N, Nagumo H, Agematsu K: IL-10 enhances B-cell IgE synthesis by promoting differentiation into plasma cells, a process that is inhibited by CD27/CD70 interaction. Clin Exp Immunol 2002;129:446-452.

26 Dong C, Juedes AE, Temann UA, Shresta S, Allison JP, Ruddle NH, Flavell RA: ICOS costimulatory receptor is essential for $\mathrm{T}$ cell activation and function. Nature 2001;409:97101.

27 Lohning M, Hutloff A, Kallinich T, Mages HW, Bonhagen K, Radbruch A, Hamelmann E, Kroczek RA: Expression of ICOS in vivo defines CD4+ effector T cells with high inflammatory potential and a strong bias for secretion of interleukin 10. J Exp Med 2003; 197:181-193.

-28 Akbari O, Freeman GJ, Meyer EH, Greenfield EA, Chang TT, Sharpe AH, Berry G, DeKruyff RH, Umetsu DT: Antigen-specific regulatory $\mathrm{T}$ cells develop via the ICOSICOS-ligand pathway and inhibit allergeninduced airway hyperreactivity. Nat Med 2002;8:1024-1032.

29 Tuettenberg A, Huter E, Hubo M, Horn J, Knop J, Grimbacher B, Kroczek RA, Stoll S, Jonuleit $\mathrm{H}$ : The role of ICOS in directing $\mathrm{T}$ cell responses: ICOS-dependent induction of $\mathrm{T}$ cell anergy by tolerogenic dendritic cells. J Immunol 2009;182:3349-3356.

30 Taylor A, Akdis M, Joss A, Akkoc T, Wenig R, Colonna M, Daigle I, Flory E, Blaser K, Akdis CA: IL-10 inhibits CD28 and ICOS costimulations of $\mathrm{T}$ cells via Src homology 2 domain-containing protein tyrosine phosphatase 1. J Allergy Clin Immunol 2007;120: $76-83$
31 Bauquet AT, Jin H, Paterson AM, Mitsdoerffer M, Ho IC, Sharpe AH, Kuchroo VK: The costimulatory molecule ICOS regulates the expression of c-Maf and IL-21 in the development of follicular T helper cells and Th-17 cells. Nat Immunol 2009;10:167-175.

32 Kaneda H, Takeda K, Ota T, Kaduka Y, Akiba H, Ikarashi Y, Wakasugi H, Kronenberg M, Kinoshita K, Yagita H, Okumura K: ICOS costimulates invariant NKT cell activation. Biochem Biophys Res Commun 2005;327: 201-207.

-33 Takahashi T, Tagami T, Yamazaki S, Uede T, Shimizu J, Sakaguchi N, Mak TW, Sakaguchi S: Immunologic self-tolerance maintained by $\mathrm{CD} 25(+) \mathrm{CD} 4(+)$ regulatory $\mathrm{T}$ cells constitutively expressing cytotoxic T lymphocyte-associated antigen 4. J Exp Med 2000;192:303-310.

- 34 Tivol EA, Borriello F, Schweitzer AN, Lynch WP, Bluestone JA, Sharpe AH: Loss of CTLA4 leads to massive lymphoproliferation and fatal multiorgan tissue destruction, revealing a critical negative regulatory role of CTLA-4. Immunity 1995;3:541-547.

35 Waterhouse P, Penninger JM, Timms E, Wakeham A, Shahinian A, Lee KP, Thompson CB, Griesser H, Mak TW: Lymphoproliferative disorders with early lethality in mice deficient in CTLA-4. Science 1995;270:985988.

-36 Read S, Malmstrom V, Powrie F: Cytotoxic T lymphocyte-associated antigen 4 plays an essential role in the function of CD25(+)CD4(+) regulatory cells that control intestinal inflammation. J Exp Med 2000;192:295-302.

- 37 Howard TD, Postma DS, Hawkins GA, Koppelman GH, Zheng SL, Wysong AK, Xu J, Meyers DA, Bleecker ER: Fine mapping of an IgE-controlling gene on chromosome 2q: analysis of CTLA4 and CD28. J Allergy Clin Immunol 2002;110:743-751.

- 38 Lee SY, Lee YH, Shin C, Shim JJ, Kang KH, Yoo SH, In KH: Association of asthma severity and bronchial hyperresponsiveness with a polymorphism in the cytotoxic $\mathrm{T}$ lymphocyte antigen-4 gene. Chest 2002;122:171176.

39 Hizawa N, Yamaguchi E, Jinushi E, Konno S, Kawakami Y, Nishimura M: Increased total serum IgE levels in patients with asthma and promoter polymorphisms at CTLA4 and FCER1B. J Allergy Clin Immunol 2001;108: 74-79.

40 Meiler F, Zumkehr J, Klunker S, Ruckert B, Akdis CA, Akdis M: In vivo switch to IL-10secreting $T$ regulatory cells in high dose allergen exposure. J Exp Med 2008;205:28872898

41 Van Overtvelt L, Wambre E, Maillere B, von Hofe E, Louise A, Balazuc AM, Bohle B, Ebo D, Leboulaire C, Garcia G, Moingeon P: Assessment of Bet v 1-specific CD4+ T cell responses in allergic and nonallergic individuals using MHC class II peptide tetramers. J Immunol 2008;180:4514-4522. 
-42 Linhart B, Bigenzahn S, Hartl A, Lupinek C, Thalhamer J, Valenta R, Wekerle T: Costimulation blockade inhibits allergic sensitization but does not affect established allergy in a murine model of grass pollen allergy. J Immunol 2007;178:3924-3931.

43 Ishida Y, Agata Y, Shibahara K, Honjo T: Induced expression of PD-1, a novel member of the immunoglobulin gene superfamily, upon programmed cell death. EMBO J 1992;11: 3887-3895.

-44 Nishimura H, Nose M, Hiai H, Minato N, Honjo T: Development of lupus-like autoimmune diseases by disruption of the PD-1 gene encoding an ITIM motif-carrying immunoreceptor. Immunity 1999;11:141-151.

-45 Freeman GJ, Long AJ, Iwai Y, Bourque K, Chernova T, Nishimura H, Fitz LJ, Malenkovich N, Okazaki T, Byrne MC, Horton HF, Fouser L, Carter L, Ling V, Bowman MR, Carreno BM, Collins M, Wood CR, Honjo T: Engagement of the PD-1 immunoinhibitory receptor by a novel $\mathrm{B} 7$ family member leads to negative regulation of lymphocyte activation. J Exp Med 2000;192:1027-1034.

-46 Latchman Y, Wood CR, Chernova T, Chaudhary D, Borde M, Chernova I, Iwai Y, Long AJ, Brown JA, Nunes R, Greenfield EA, Bourque K, Boussiotis VA, Carter LL, Carreno BM, Malenkovich N, Nishimura $\mathrm{H}$, Okazaki T, Honjo T, Sharpe AH, Freeman GJ: PD-L2 is a second ligand for PD-1 and inhibits T cell activation. Nat Immunol 2001; 2:261-268.

-47 Tseng SY, Otsuji M, Gorski K, Huang X, Slansky JE, Pai SI, Shalabi A, Shin T, Pardoll DM, Tsuchiya H: B7-DC, a new dendritic cell molecule with potent costimulatory properties for T cells. J Exp Med 2001;193:839-846.

-48 Matsumoto K, Fukuyama S, Eguchi-Tsuda M, Nakano T, Matsumoto T, Matsumura M, Moriwaki A, Kan-o K, Wada Y, Yagita H, Shin T, Pardoll DM, Patcharee R, Azuma M, Nakanishi Y, Inoue H: B7-DC induced by IL13 works as a feedback regulator in the effector phase of allergic asthma. Biochem Biophys Res Commun 2008;365:170-175.

-49 Matsumoto K, Inoue H, Nakano T, Tsuda M, Yoshiura Y, Fukuyama S, Tsushima F, Hoshino T, Aizawa H, Akiba H, Pardoll D, Hara N, Yagita H, Azuma M, Nakanishi Y: B7-DC regulates asthmatic response by an IFNgamma-dependent mechanism. J Immunol 2004;172:2530-2541.

-50 Radhakrishnan S, Iijima K, Kobayashi T, Rodriguez M, Kita H, Pease LR: Blockade of allergic airway inflammation following systemic treatment with a B7-dendritic cell (PD-L2) cross-linking human antibody. J Immunol 2004;173:1360-1365.

- 51 Oflazoglu E, Swart DA, Anders-Bartholo P, Jessup HK, Norment AM, Lawrence WA, Brasel K, Tocker JE, Horan T, Welcher AA, Fitzpatrick DR: Paradoxical role of programmed death-1 ligand 2 in Th2 immune responses in vitro and in a mouse asthma model in vivo. Eur J Immunol 2004;34:3326-3336.
52 Fukushima A, Yamaguchi T, Azuma M, Yagita $\mathrm{H}$, Ueno $\mathrm{H}$ : Involvement of programmed death-ligand 2 (PD-L2) in the development of experimental allergic conjunctivitis in mice. Br J Ophthalmol 2006;90: 1040-1045.

53 Gajewska BU, Tafuri A, Swirski FK, Walker T, Johnson JR, Shea T, Shahinian A, Goncharova S, Mak TW, Stampfli MR, Jordana M: B7RP-1 is not required for the generation of Th2 responses in a model of allergic airway inflammation but is essential for the induction of inhalation tolerance. J Immunol 2005;174:3000-3005.

54 Kim HK, Guan H, Zu G, Li H, Wu L, Feng X, Elmets C, Fu Y, Xu H: High-level expression of B7-H1 molecules by dendritic cells suppresses the function of activated $\mathrm{T}$ cells and desensitizes allergen-primed animals. J Leukoc Biol 2006;79:686-695.

55 Tsushima F, Iwai H, Otsuki N, Abe M, Hirose $\mathrm{S}$, Yamazaki T, Akiba H, Yagita H, Takahashi Y, Omura K, Okumura K, Azuma M: Preferential contribution of $\mathrm{B} 7-\mathrm{H} 1$ to programmed death-1-mediated regulation of hapten-specific allergic inflammatory responses. Eur J Immunol 2003;33:27732782.

56 Piconi S, Trabattoni D, Saresella M, Iemoli E, Schenal M, Fusi A, Borelli M, Chen L, Mascheri A, Clerici M: Effects of specific immunotherapy on the B7 family of costimulatory molecules in allergic inflammation. J Immunol 2007;178:1931-1937.

57 Allam JP, Novak N, Fuchs C, Asen S, Berge S, Appel T, Geiger E, Kochan JP, Bieber T: Characterization of dendritic cells from human oral mucosa: a new Langerhans' cell type with high constitutive FcepsilonRI expression. J Allergy Clin Immunol 2003;112: $141-148$

58 Allam JP, Peng WM, Appel T, Wenghoefer $M$, Niederhagen B, Bieber T, Berge S, Novak $\mathrm{N}$ : Toll-like receptor 4 ligation enforces tolerogenic properties of oral mucosal Langerhans cells. J Allergy Clin Immunol 2008; 121:368-374

59 Nagashima O, Harada N, Usui Y, Yamazaki T, Yagita H, Okumura K, Takahashi K, Akiba H: B7-H3 contributes to the development of pathogenic Th2 cells in a murine model of asthma. J Immunol 2008;181:4062-4071.

60 Fukushima A, Sumi T, Fukuda K, Kumagai N, Nishida T, Yamazaki T, Akiba H, Okumura K, Yagita H, Ueno H: B7-H3 regulates the development of experimental allergic conjunctivitis in mice. Immunol Lett 2007 113:52-57.

61 Chen AI, McAdam AJ, Buhlmann JE, Scott S, Lupher ML Jr, Greenfield EA, Baum PR, Fanslow WC, Calderhead DM, Freeman GJ, Sharpe AH: OX40-ligand has a critical costimulatory role in dendritic cell: $\mathrm{T}$ cell interactions. Immunity 1999;11:689-698.
62 Ohshima Y, Yang LP, Uchiyama T, Tanaka Y, Baum P, Sergerie M, Hermann P, Delespesse G: OX40 costimulation enhances interleukin-4 (IL-4) expression at priming and promotes the differentiation of naive human CD4(+) T cells into high IL-4-producing effectors. Blood 1998;92:3338-3345.

63 Ito T, Wang YH, Duramad O, Hori T, Delespesse GJ, Watanabe N, Qin FX, Yao Z, Cao W, Liu YJ: TSLP-activated dendritic cells induce an inflammatory $\mathrm{T}$ helper type 2 cell response through OX40 ligand. J Exp Med 2005;202:1213-1223.

-64 Hoshino A, Tanaka Y, Akiba H, Asakura Y, Mita Y, Sakurai T, Takaoka A, Nakaike S, Ishii N, Sugamura K, Yagita H, Okumura K: Critical role for OX40 ligand in the development of pathogenic Th2 cells in a murine model of asthma. Eur J Immunol 2003;33: 861-869.

65 Salek-Ardakani S, Song J, Halteman BS, Jember AG, Akiba H, Yagita H, Croft M: OX40 (CD134) controls memory T helper 2 cells that drive lung inflammation. J Exp Med 2003;198:315-324.

66 Jember AG, Zuberi R, Liu FT, Croft M: Development of allergic inflammation in a murine model of asthma is dependent on the costimulatory receptor OX40. J Exp Med 2001; 193:387-392.

67 Duan W, So T, Croft M: Antagonism of airway tolerance by endotoxin/lipopolysaccharide through promoting OX40L and suppressing antigen-specific Foxp3+ T regulatory cells. J Immunol 2008;181:86508659.

68 So T, Salek-Ardakani S, Nakano H, Ware CF, Croft M: TNF receptor-associated factor 5 limits the induction of Th2 immune responses. J Immunol 2004;172:4292-4297.

-69 Vu MD, Xiao X, Gao W, Degauque N, Chen M, Kroemer A, Killeen N, Ishii N, Chang Li X: OX40 costimulation turns off Foxp3+ Tregs. Blood 2007;110:2501-2510.

70 Gri G, Piconese S, Frossi B, Manfroi V, Merluzzi S, Tripodo C, Viola A, Odom S, Rivera J, Colombo MP, Pucillo CE: CD4+CD25+ regulatory $\mathrm{T}$ cells suppress mast cell degranulation and allergic responses through OX40-OX40L interaction. Immunity 2008; 29:771-781.

-71 Diana J, Griseri T, Lagaye S, Beaudoin L, Autrusseau E, Gautron AS, Tomkiewicz C, Herbelin A, Barouki R, von Herrath M, Dalod M, Lehuen A: NKT cell-plasmacytoid dendritic cell cooperation via OX40 controls viral infection in a tissue-specific manner. Immunity 2009;30:289-299.

72 Zaini J, Andarini S, Tahara M, Saijo Y, Ishii N, Kawakami K, Taniguchi M, Sugamura K, Nukiwa T, Kikuchi T: OX40 ligand expressed by DCs costimulates NKT and CD4+ Th cell antitumor immunity in mice. J Clin Invest 2007;117:3330-3338. 
73 Heshmat NM, El-Hadidi ES: Soluble CD30 serum levels in atopic dermatitis and bronchial asthma and its relationship with disease severity in pediatric age. Pediatr Allergy Immunol 2006;17:297-303.

74 Oflazoglu E, Simpson EL, Takiguchi R, Grewal IS, Hanifin JM, Gerber HP: CD30 expression on CD1a+ and CD8+ cells in atopic dermatitis and correlation with disease severity. Eur J Dermatol 2008;18:41-49.

75 Rojas-Ramos E, Garfias Y, Jimenez-Martinez Mdel C, Martinez-Jimenez N, Zenteno E, Gorocica P, Lascurain R: Increased expression of CD30 and CD57 molecules on CD4(+) $\mathrm{T}$ cells from children with atopic asthma: a preliminary report. Allergy Asthma Proc 2007;28:659-666.

76 Foschi FG, Emiliani F, Savini S, Quercia O Stefanini GF: CD30 serum levels and response to hymenoptera venom immunotherapy. J Investig Allergol Clin Immunol 2008;18:279-283.

77 Croft M: The role of TNF superfamily mem bers in $\mathrm{T}$ cell function and diseases. Nat Rev Immunol 2009;9:271-285.

78 Heinisch IV, Bizer C, Volgger W, Simon HU: Functional CD137 receptors are expressed by eosinophils from patients with IgE-mediated allergic responses but not by eosinophils from patients with non-IgE-mediated eosinophilic disorders. J Allergy Clin Immunol 2001;108:21-28.

79 Cho YS, Kwon B, Lee TH, Kim TB, Moon KA, La S, Lee J, Lee SD, Oh YM, Moon HB: 4-1BB stimulation inhibits allergen-specific immunoglobulin E production and airway hyper-reactivity but partially suppresses bronchial eosinophilic inflammation in a mouse asthma model. Clin Exp Allergy 2006;36:377-385.

$>80$ Nishimoto H, Lee SW, Hong H, Potter KG, Maeda-Yamamoto M, Kinoshita T, Kawakami Y, Mittler RS, Kwon BS, Ware CF, Croft M, Kawakami T: Costimulation of mast cells by $4-1 \mathrm{BB}$, a member of the tumor necrosis factor receptor superfamily, with the highaffinity IgE receptor. Blood 2005;106:42414248.

-81 Polte T, Foell J, Werner C, Hoymann HG, Braun A, Burdach S, Mittler RS, Hansen G: CD137-mediated immunotherapy for allergic asthma. J Clin Invest 2006;116:10251036.
82 Polte T, Jagemann A, Foell J, Mittler RS, Hansen G: CD137 ligand prevents the development of $\mathrm{T}$ helper type 2 cell-mediated allergic asthma by interferon-gamma-producing CD8+ T cells. Clin Exp Allergy 2007;37: 1374-1385.

83 Fukushima A, Yamaguchi T, Ishida W, Fukata K, Mittler RS, Yagita H, Ueno H: Engagement of 4-1BB inhibits the development of experimental allergic conjunctivitis in mice. J Immunol 2005; 175:4897-4903.

84 Tsuyuki S, Bertrand C, Erard F, Trifilieff A, Tsuyuki J, Wesp M, Anderson GP, Coyle AJ: Activation of the Fas receptor on lung eosinophils leads to apoptosis and the resolution of eosinophilic inflammation of the airways. J Clin Invest 1995;96:2924-2931.

85 Duez C, Tomkinson A, Shultz LD, Bratton DL, Gelfand EW: Fas deficiency delays the resolution of airway hyperresponsiveness after allergen sensitization and challenge. $\mathrm{J} \mathrm{Al}$ lergy Clin Immunol 2001;108:547-556.

-86 Tong J, Bandulwala HS, Clay BS, Anders RA, Shilling RA, Balachandran DD, Chen B, Weinstock JV, Solway J, Hamann KJ, Sperling AI: Fas-positive T cells regulate the resolution of airway inflammation in a murine model of asthma. J Exp Med 2006;203:11731184.

87 Chuang YH, Suen JL, Chiang BL: Fas-ligandexpressing adenovirus-transfected dendritic cells decrease allergen-specific $\mathrm{T}$ cells and airway inflammation in a murine model of asthma. J Mol Med 2006;84:595-603.

$>8$ Uller L, Rydell-Tormanen K, Persson CG, Erjefalt JS: Anti-Fas mAB induced apoptosis and cytolysis of airway tissue eosinophils aggravates rather than resolves established inflammation. Respir Res 2005;6:90.

89 Goodwin RG, Alderson MR, Smith CA, Armitage RJ, VandenBos T, Jerzy R, Tough TW, Schoenborn MA, Davis-Smith T, Hennen K, et al: Molecular and biological characterization of a ligand for CD27 defines a new family of cytokines with homology to tumor necrosis factor. Cell 1993;73:447-456.

$\checkmark 90$ Agematsu K, Kobata T, Sugita K, Hirose T, Schlossman SF, Morimoto C: Direct cellular communications between CD45RO and CD45RA T cell subsets via CD27/CD70. J Immunol 1995;154:3627-3635.
91 Sumi T, Ishida W, Ojima A, Kajisako M, Sakanishi T, Yagita H, Fukushima A: CD27 and CD70 do not play a critical role in the development of experimental allergic conjunctivitis in mice. Immunol Lett 2008;119: 91-96.

-92 Grewal IS, Flavell RA: CD40 and CD154 in cell-mediated immunity. Annu Rev Immunol 1998;16:111-135.

93 Poulsen LK, Hummelshoj L: Triggers of IgE class switching and allergy development. Ann Med 2007;39:440-456.

-94 LeiXF, Ohkawara Y,StampfliMR, Mastruzzo C, Marr RA, Snider D, Xing Z, Jordana M: Disruption of antigen-induced inflammatory responses in CD40 ligand knockout mice. J Clin Invest 1998;101:1342-1353.

$\$ 95$ Wiley JA, Geha R, Harmsen AG: Exogenous CD40 ligand induces a pulmonary inflammation response. J Immunol 1997;158: 2932-2938.

96 Suzuki M, Zheng X, Zhang X, Ichim TE, Sun H, Kubo N, Beduhn M, Shunnar A, Garcia B, Min WP: Inhibition of allergic responses by CD40 gene silencing. Allergy 2009;64:387-397.

$\checkmark 97$ Moingeon P, Chang HC, Sayre PH, Clayton LK, Alcover A, Gardner P, Reinherz EL: The structural biology of CD2. Immunol Rev 1989;111:111-144.

98 Wingren AG, Parra E, Varga M, Kalland T, Sjogren HO, Hedlund G, Dohlsten M: T cell activation pathways: B7, LFA-3, and ICAM1 shape unique $\mathrm{T}$ cell profiles. Crit Rev Immunol 1995;15:235-253.

99 Biancone L, Andres G, Ahn H, Lim A, Dai C, Noelle R, Yagita H, De Martino C, Stamenkovic I: Distinct regulatory roles of lymphocyte costimulatory pathways on $\mathrm{T}$ helper type-2 mediated autoimmune disease. J Exp Med 1996;183:1473-1481.

100 Taylor A, Verhagen J, Akkoc T, Wenig R, Flory E, Blaser K, Akdis M, Akdis CA: IL-10 suppresses CD2-mediated $\mathrm{T}$ cell activation via SHP-1. Mol Immunol 2009;46:622629.

101 Cheng YX, Foster B, Holland SM, Klion AD, Nutman TB, Casale TB, Metcalfe DD, Prussin C: CD2 identifies a monocyte subpopulation with immunoglobulin E-dependent, high-level expression of Fc epsilon RI. Clin Exp Allergy 2006;36:1436-1445. 